\title{
Effect of Corporate Governance And Disclosure of Corporate Social Responsibility on The Quality of Financial Statements
}

Winda Pramudita Rusady1, Andrian Budi Prasetyo ${ }^{2}$

\begin{abstract}
Accounting Department Faculty of Economics and Business Universitas Diponegoro, Jalan Prof. Soedarto, SH, Tembalang, Semarang, 50275, Central Java, Indonesia
\end{abstract}

\section{A R T I C L E I N F O \\ Article history: \\ Received 11 Oktober 2018 \\ Revised 14 Desember 2018 \\ Accepted 25 Desember 2018}

Key words:

Financial reports quality, corporate social responsibility disclosure, corporate Governance

\begin{abstract}
A B S T R A C T
The aim of this study was to analyze the effect of the disclosure of corporate social responsibility on the quality of the financial reports and the disclosure of corporate social responsibility mediation on the financial report quality of corporate governance. The dependent variable, financial report quality, was measured by earnings management (RAM); while, the independent variables, corporate social responsibility disclosure and corporate governance, were measured by CSR index and CGI index. Meanwhile, the control variables were the negative value of operating cash flow, profit, debt ratio, market volatility, and operating cycle. The sample was manufacturing companies listed in Indonesia Stock Exchange in the period of 2013-2015. The sampling method was purposive sampling and the technique of analysis was multiple linear regression. The results showed that corporate social responsibility disclosure significantly and negatively affected RAM and the mediation of corporate social responsibility disclosure on the effect of corporate governance did not affect the quality of the financial reports.
\end{abstract}

\begin{abstract}
A B S T R A K
Penelitian ini bertujuan untuk menganalisis pengaruh pengungkapan corporate social responsibility terhadap kualitas laporan keuangan dan mediasi pengungkapan corporate social responsibility pada tata kelola perusahaan terhadap kualitas laporan keuangan. Kualitas laporan keuangan berperan sebagai variabel dependen yang diukur dengan manajemen laba (RAM). Pengungkapan corporate social responsibility dan tata kelola perusahaan berperan sebagai variabel independen yang diukur dengan indeks CSR dan indeks CGI. Penelitian ini menggunakan kerugian arus kas operasi, laba, rasio hutang, volatilitas pasar, dan siklus operasi sebagai variabel kontrol. Sampel penelitian ini adalah perusahaan manufaktur yang terdaftar dalam Bursa Efek Indonesia selama periode 2013-2015. Metode pengambilan sampel dalam penelitian adalah purposive sampling. Teknik analisis yang digunakan adalah analisis regresi linear berganda. Secara keseluruhan, hasil penel $i-$ tian menunjukkan bahwa corporate social responsibility berpengaruh negatif terhadap RAM. Tidak terdapat mediasi pengungkapan corporate social responsibility pada pengaruh tata kelola perusahaan terhadap kualitas keuangan.
\end{abstract}

\section{INTRODUCTION}

Many researchers have studied Corporate Social Responsibility (CSR) as a subject that closely related to the performance of an organization. World Business Council's report on sustainable development categorized companies disclosing CSR issues into employee equity, human rights, environmental protection, community participation, supplier relations, transparency and disclosure, and stakeholder equity (Chiang, He, and
Shiao, 2015). The obligation to apply CSR in Indonesia is stipulated in Law No. 25, 2007 on Capital Investment (UUPM) and Law No.40 of 2007 on Limited Liability Company (UUPT) stating that every investor or company has an obligation to carry out social responsibility of the company (Yintayani, 2011).

The voluntary and transparent disclosure of CSR on the financial statements is important because high quality of financial statement will not only

* Corresponding author, email address: 2andrianbp1589@live.undip.ac.id 
used as the basis for decision making on investment but also it increases the value of the company. The assumption of agency theory, however, suggested that managers are occasionally selfish and disclose the CSR only when it makes a profit. Based on this theoretical assumption, the company invests CSR only to disguise profit manipulation, which can affect the financial statements quality negatively (Prior et al., 2008). Furthermore, the level of profit manipulation done by corporate managers can be influenced by the degree of independence and corporate governance. If the degree of the earnings management is high, the quality of the financial reports will be lower (Chiang et al., 2015).

Furthermore, companies disclosing CSR might affect the financial report in both positive and negative ways. Positively, the companies' disclosure increases the profit and the value of the firms; while, in negative way, the disclosure might be used to cover the earning management. The earning management taken place in a company can be influenced by corporate governance, as (Chiang et al., 2015) stated that good corporate governance decreases earning management; while, bad corporate governance increases earning management. Therefore, corporate governance, CSR disclosure, and quality of financial statements were closely related.

However, the point that makes this study different from the previous ones is that the variable of the financial report's quality is proxy by earning management, in which the proxy could clearly describe the quality of the financial report; and, the population are companies listed in Indonesia.

Given this situation, the objectives of this study were to analyze and find empirical evidence of the influence of CSR disclosure on the financial statements quality and the mediation disclosure of CSR on the influence of corporate governance on the quality of financial statements.

\section{THEORETICAL FRAMEWORK AND HYPOTHESES}

CSR disclosure might affect the quality of the financial statements in a positive or negative manner. The positive influence takes place when CSR disclosure is reported voluntary and transparent. However, a negative effect occurs when CSR disclosures are made solely for profit oriented by disguising earnings manipulation by corporate managers. In addition, corporate governance can also affect the level of profit manipulation by managers by disguising the CSR disclosure result- ing in low quality of corporate financial statements. Apart from the discussion, there were factors might affect the quality of the financial statements indirectly consisting of operating cash flows, corporate profits, debt ratios, risks to company assets, and operating cycles.

The Influence of CSR Disclosures on the Quality of the Company's Financial Statements

Financial statements quality has been used as the basis for making decisions of an investment; the higher the quality level of the financial statements is, the more increase the value of the company will be. However, the agency theory assumption revealed that self-interest driven managers disclose CSR as an instrument and only promote activities of CSR when it generates profit (Karnani, 2010). Nevertheless, companies can also develop CSR even though it may reduce profits from corporate's stakeholders (Reinhardt, Stavins, and Vietor, 2008); yet, CSR disclosure positively affect the quality of the financial statement (Selewski and Zulch, 2012). In this case, the level of earnings management by managers might be lower, but the quality of the financial reports would be high.

H1. CSR disclosure positively affects the quality of financial statements of a company.

Mediation of CSR Disclosure on the Influence of Corporate Governance on the Quality of Financial Statements

Previous studies showed that based on agency theory, corporate governance influences financial report's quality. Using one of the variables of governance mechanism - the independence of the board of commissioners - the result showed that the higher the independence of the board of commissioners is, the lower the possibility of the earning management to happen will be (Dechow et al., 1996; Hillman and Dalziel, 2003). Meanwhile, other studies using stewardship theory showed that corporate governance affects the CSR fund spent by a company; therefore, board of directors will combine both personal and corporate interests (Davis et al., 19970).

The agency theory stated that the closer the relationship between the company and stakeholders is, the more active the company to invest in CSR and disclose it in the company's financial statements will be. In addition, corporate governance can also affect the level of profit manipulation performed by managers by disguising CSR disclosure (Chiang et al., 2015). Thus, there might be a mediation between the influences of corporate governance and the quality of financial 
statements.

H2. CSR disclosure mediates the influence of corporate governance on the financial statements quality.

The influence of Corporate Governance on the Quality of the Financial Statement

According to agency theory, the mechanism quality of the corporate governance influences the financial report's quality of a company. Previous study showed that dualism of CEO as a result of board of directors also function as board of commissioners causes supervision function decreases leading to the intention of doing earning management resulting the inconclusive of the financial report (Core et al., 1999; Shivdasani and Yermack, 1999; Anderson et al., 2004). Therefore, the hypothesis 3 is formulated as follows:

H3. Corporate Governance positively influences the quality of the Financial Report

\section{RESEARCH METHOD}

The dependent variable was financial statements quality, and the independent variables were CSR disclosure and corporate governance; while, the control variables were operating cash flow losses, corporate profits, debt ratios, risks on corporate assets, and operating cycles. The quality of the financial statements was measured using earnings management (RAM) of Roychowdhury (2006). He proposed that profit management measurement is divided into cash flow from abnormal cash flow operating (AB_CFO), abnormal production cost (AB_PROD), and abnormal discretionary expenditure (AB_DISEXP). The comprehensive index for earnings management (RAM) is AB_CFO + AB_PROD - AB_DISEXP. The measurement model did not use discretionary accruals because, according to some researchers, the model has not been able to disclose the complete conditions of earnings management practices as they ignore the relationship between cash flow and accrual transactions (Kothari, Leone, and Wasley, 2005).

The CSR disclosure was measured using CSR disclosure index (Sembiring, 2005). The measurement was conducted by giving a value of 1 on each item if the company did the disclosure of the item, and a value of 0 if the company did not disclose the item. The value of each item was summed up to be an overall company value. Furthermore, the CSR index was obtained by dividing the overall company value by the item that should be disclosed by the company, and Corporate Governance Index (CGI Index) was used to measure corporate governance (CG) (Black et al., 2006). The measurements was done by giving a value of 1 on each item if the company did the disclosure of the item, and a value of 0 if the company did not disclose the item. The value of each item was summed up to be the company's overall value. Furthermore, the CGI index was obtained by dividing the overall company value by the total item that should be disclosed by the company.

The control variable of negative cash flow operating (NEGCFO) and corporate earnings (LOSSD) was measured by dummy variable; while, debt ratio (LEV) was measured by dividing the total liabilities to the total assets of the company. The risk on the company's assets (BETA) was measured by market volatility, while operating cycle (OC) was measured by the average number of days the collection of receivables and the average number of days of inventory turnover. The control variable was used because the quality of the company's financial statements will also be influenced by the company's financial ratios, in other words, the company's financial ratios reflected the quality of financial statements.

$\mathrm{T}$ he population chosen was Indonesian go public company within 2013-2015 sampled by purposive sampling method and the sample was selected based on certain criteria;

1. Companies listed on the Stock Exchange in 2012-2015 for updating data.

2. Companies publishing annual report on BEI in 2012-2015.

3. Companies using rupiah currency in their financial statements to avoid bias.

4. Companies included in manufacturing enterprises comprising basic and chemical industries, other industries, and consumer goods industries. Manufacturing companies consisting of basic industrial as well as chemical sectors, other industries, and consumer goods industries were the most important industrial sectors to implement CSR, because the three sectors, in carrying out their operations, greatly influenced the surrounding environment in creating pollution, such as, environmental, water, and waste pollution.

Based on these criteria, the total manufacturing companies in Indonesia sampled was 78 . Within three years of research, 2013-2015, the total sample was 234 .

This study used secondary data obtained from pre-existing data generated from the annual 
report in 2012-2015 obtained from the Indonesia Stock Exchange (BEI).

The statistical analysis technique was multiple linear regression and Sobel test. The statistical model used for hypothesis 1 is as follows:

$\mathrm{FQR}_{\mathrm{t}}(\mathrm{RAM})=\mathrm{a}_{0}+\mathrm{a}_{1} \mathrm{CSR}+\mathrm{a}_{2} \mathrm{NEGCFO}+$ $\mathrm{a}_{3} \mathrm{LOSSD}+\mathrm{a}_{4} \mathrm{LEV}+\mathrm{a}_{5} \mathrm{BETA}+\mathrm{a}_{6} \mathrm{OC}+\varepsilon$

Note:

FQRt $($ RAM) = Quality of financial statements as measured by earnings management

$\begin{array}{ll}\text { CSR } & =\text { CSR Disclosure } \\ \text { NEGCFO } & =\text { Negative Cash Flow Operating } \\ \text { LOSSD } & =\text { Profit } \\ \text { LEV } & =\text { Debt ratio measured by dividing }\end{array}$

LEV = Debt ratio measured by divi
the total liabilities by total assets of the firm

BETA = Systematic risk for corporate assets measured by market volatility

OC= Operating cycle measured by the average amount of receivables and the average number of days inventory turnover

The statistical model used for hypothesis 2 is as follows:

$\mathrm{CSR}_{\mathrm{t}}$

$=\mathrm{a}_{0}+\mathrm{a}_{1} \mathrm{CGI}$

Note:

$\mathrm{CSR}_{\mathrm{t}}=$ CSRDisclosure

CSRCGI= Corporate governance

\section{DATA ANALYSIS AND DISCUSSION Uji Validitas dan Uji Reliabilitas}

The sample was determined by purposive sampling method with 234 samples consisting of 78 manufacturing companies listed on the Stock Exchange in 2013-2015. Table 1 shows the description of the sample.

Table 1

Sample

\begin{tabular}{ll}
\hline \multicolumn{3}{c}{ Sample } & Total \\
\hline Criteria & 147 \\
Number of manufacturing \\
Exchange in 2012-2015.
\end{tabular}

Source: Primary Data Processed, 2017.
Table 1 shows that there are 147 manufacturing companies listed on BEI in 2012-2015. However, after analyzing the data based on the criteria, there were 78 companies listed on the BEI in 2012-2015 that met the criteria to be studied. Therefore, the total final samples observed for this study were 234 .

Descriptive statistical analysis shows information on the number of samples, minimum values, maximal values, mean values, and standard deviations of the samples used in the study. Table 2 is a descriptive statistic of the eight variables identified.

Table 2

Descriptive statistics

\begin{tabular}{|c|c|c|c|c|c|}
\hline & $\mathrm{N}$ & $\begin{array}{l}\text { Min- } \\
\text { imum }\end{array}$ & $\begin{array}{l}\text { Max- } \\
\text { imum }\end{array}$ & $\begin{array}{l}\text { Me } \\
\text { an }\end{array}$ & $\begin{array}{l}\text { Std. } \\
\text { Devi- } \\
\text { ation }\end{array}$ \\
\hline \multicolumn{6}{|c|}{ Independent Variable } \\
\hline \multirow[t]{3}{*}{ CSR } & 2 & 0.051 & 0.679 & 0.26 & 0,128 \\
\hline & 3 & & & 303 & 089. \\
\hline & 4 & & & & \\
\hline \multirow[t]{3}{*}{$\mathrm{CG}$} & 2 & 0.200 & 0.7333 & 0.53 & 0.109 \\
\hline & 3 & 0 & & 359 & 6567 \\
\hline & 4 & & & & \\
\hline \multicolumn{6}{|c|}{ Dependent Variable } \\
\hline \multirow[t]{3}{*}{ RAM } & 2 & - & 1.5916 & - & 0.586 \\
\hline & 3 & 2.670 & & 1.03 & 3546 \\
\hline & 4 & 3 & & 39 & \\
\hline \multicolumn{6}{|c|}{ Control Variable } \\
\hline NEG & 2 & 0.000 & 1.0000 & 0.20 & 0.407 \\
\hline \multirow[t]{2}{*}{$\mathrm{CFO}$} & 3 & 0 & & 940 & 7538 \\
\hline & 4 & & & & \\
\hline LOSS & 2 & 0.000 & 1.0000 & 0.79 & 0.404 \\
\hline \multirow[t]{2}{*}{$\mathrm{D}$} & 3 & 0 & & 487 & 6609 \\
\hline & 4 & & & & \\
\hline \multirow[t]{3}{*}{ LEV } & 2 & 0.037 & 3.0291 & 0.51 & 0.382 \\
\hline & 3 & 2 & & 374 & 0015 \\
\hline & 4 & & & & \\
\hline BE- & 2 & 0.000 & 343.51 & 50.9 & 50.58 \\
\hline \multirow[t]{2}{*}{ TA } & 3 & 0 & 00 & 939 & 4088 \\
\hline & 4 & & & & \\
\hline \multirow[t]{3}{*}{$\mathrm{OC}$} & 2 & 7.516 & 198.21 & 62.5 & 32.11 \\
\hline & 3 & 0 & 20 & 070 & 2082 \\
\hline & 4 & & & & \\
\hline
\end{tabular}

Source: Secondary data processed, 2017.

The classical assumption test consists of normality test, multicollinearity test, heteroscedasticity test, and autocorrelation test. The results of the classical assumption test concluded that: 
1. The normality test in this research was conducted using histogram graphic test, plot graph, and non-parametric test of Kolmogorov-Smirnov (K-S). The results of the histogram graph showed that the data formed a perfect bell. The plot graph showed normal distributed residual results as indicated by the distribution of data approaching the diagonal axis. Meanwhile, the Kolmogorov-Smirnov test showed Asym Sig of 0.521, meaning that the value was greater than the significance value of the normality assumption of 0.05 . The conclusion was that this study met the normality test.

2. The result of the Multicollinearity test showed that each independent variable showed the tolerance value $\geq 0.10$ and VIF $\leq$ 10;thus, this research did not have multicollinearity.

3. Heteroscedasticity test was conducted by looking at the scatterplot graphic and glejser test. The result of the scatterplot graphic showed that the data were scattered randomly and did not form a certain pattern. The results of the glejser test showed the significance values above $5 \%$ confidence level. Therefore, there was no independent variables that statistically and significantly influenced the dependent variable. Thus, it could be concluded that the Heteroscedasticity model did not occur in this research.

4. The autocorrelation test was performed based on Durbin-Watson (DW) value. The results showed that the DW value was 1.862 , which had a value of greater than du which was 1.83771 and less than 4 - du (4 $1.83771=2.16229)$. So, it could be concluded that this research model had no autocorrelation.

Based on the calculations using multiple linear regression equations and Sobel test, the result is as follows:
Table 3

Model 1: Analysis of Multiple Linear Regression

\begin{tabular}{|c|c|c|c|c|c|}
\hline \multirow{2}{*}{ Model } & \multicolumn{2}{|c|}{$\begin{array}{l}\text { Unstandardized } \\
\text { Coefficients }\end{array}$} & \multirow{2}{*}{$\begin{array}{l}\text { Stan- } \\
\text { dardize } \\
\text { Coeffi- } \\
\text { cients } \\
\text { Beta }\end{array}$} & \multirow{2}{*}{$t$} & \multirow{2}{*}{ Sig. } \\
\hline & B & $\begin{array}{l}\text { Std. } \\
\text { Error }\end{array}$ & & & \\
\hline $\begin{array}{l}1 \\
\text { (Con- } \\
\text { stant) }\end{array}$ & $-0,090$ & 0,217 & & $-0,415$ & 0,679 \\
\hline CSR & $-0,009$ & 0,004 & $-0,158$ & $-2,443$ & 0,015 \\
\hline $\mathrm{CG}$ & $-0,727$ & 0,346 & $-0,136$ & $-2,103$ & 0,037 \\
\hline $\begin{array}{l}\text { NEGC } \\
\mathrm{FO}\end{array}$ & 0,176 & 0,089 & 0,122 & 1,968 & 0,050 \\
\hline $\begin{array}{l}\text { LOSS } \\
\text { D }\end{array}$ & $-0,266$ & 0,094 & $-0,183$ & $-2,824$ & 0,005 \\
\hline LEV & $-0,396$ & 0,096 & $-0,258$ & $-4,120$ & 0,000 \\
\hline BETA & $-0,002$ & 0,001 & $-0,142$ & $-2,385$ & 0,018 \\
\hline$\overline{O C}$ & 0,002 & 0,001 & 0,084 & 1,387 & 0,167 \\
\hline
\end{tabular}

Source: Secondary data processed, 2017.

Table 4

Model 2: Analysis of Multiple Linear Regression

\begin{tabular}{|c|c|c|c|c|c|}
\hline \multirow{2}{*}{ Model } & \multicolumn{2}{|c|}{$\begin{array}{l}\text { Unstandardized } \\
\text { Coefficients }\end{array}$} & \multirow{2}{*}{$\begin{array}{l}\text { Standardized } \\
\text { Coefficients } \\
\text { Beta }\end{array}$} & \multirow{2}{*}{$\mathrm{t}$} & \multirow{2}{*}{ Sig. } \\
\hline & B & $\begin{array}{l}\text { Std. } \\
\text { Error }\end{array}$ & & & \\
\hline $\begin{array}{l}1 \quad \text { (Con- } \\
\text { stant) }\end{array}$ & 0,041 & 0,039 & & 1,050 & 0,295 \\
\hline $\mathrm{CG}$ & 0,416 & 0,072 & 0,356 & 5,808 & 0,000 \\
\hline
\end{tabular}

Source: Secondary data processed, 2017.

The result of the regression test supports the hypothesis if it matches as it predicted. Tables 3 and 4 show the results of multiple regression test that underlies the decision whether the hypothesis is accepted or rejected. Figure 1 shows the influential relationship directly and mediation.

Figure 1

Path Analysis

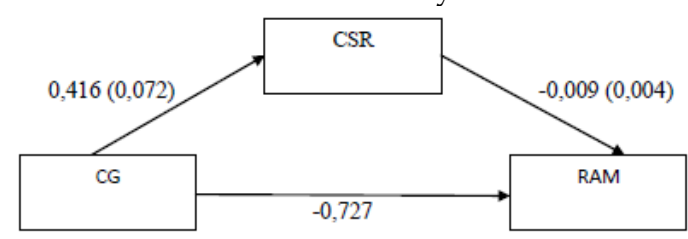

The first hypothesis (H1) stated that CSR disclosure positively affects the quality of corporate financial statements. The result of the first hypothesis tested proved that the CSR disclosure significantly and negatively affected earnings management as shown in table 3 that the value of the $t$ table was- 2.443 and significance at 0.015 or the value was lower than 0.05 . The negative effect 
of the CSR disclosure on earnings management suggested that the level of the earning management level was low. Mostly, a low level of earnings management might result in a high quality of financial reports. Therefore, the disclosure of CSR positively affected the quality of financial statements; thus, the first hypothesis is accepted.

This finding was in accordance with the one of Chiang et al. (2015) that a company disclosing CSR can reduce its involvement in earnings management; as a result, the company can provide relatively more transparent financial information and improve the quality of the financial statements. In such a case, managers not affected by self-interest when making a decision on company's policy might avoid behaviors to the detriment of the company by refraining from disguising profit manipulation using CSR. Such behavior could produce highly qualified financial reports. This study was in line with the one of Reinhardt et al., (2008) stated that based on agency theory companies also develop CSR even though it can reduce the profits of corporate stakeholders. Therefore, managers are not affected by selfinterest when pushing company policies.

The second hypothesis (H2) stated that CSR disclosure mediates the influence of corporate governance on the quality of financial statements. The results of the second hypothesis tested suggested that the second hypothesis (H2) was rejected proven by the Sobel test, which showed the absence of mediation disclosure of CSR on the influence of corporate governance on the quality of financial statements. The result of the Sobel test was that the $t$ value was equal to -5.756 , which was smaller than the $t$ table of 1.97 at the significance level of 0.05 . Thus, the hypothesis tested was not in accordance with the finding of Chiang et al., (2015).

However, the test result indicated that the corporate governance with qualified financial statements significantly and negatively had a direct relationship. This result was proven by the statistical $t$ tests exhibited in table 3 that the value of direct influence between corporate governance and financial statements quality was $\mathrm{t}-2.103$, significance at 0.037 , or lower than 0,05 . This finding showed that there was no mediation upon CSR disclosure on the effect of corporate governance on the financial statement quality. The reason was that the results of direct influence indicated that good corporate governance could reduce the level of earnings management performed by managers. Low level of earnings management meant that the quality of corporate financial statements could be improved. Besides, corporate governance system would control and supervise directly and effectively to reduce the level of earnings management performed by managers. Thus, corporate governance had no effect on the level of earnings management performed by managers through CSR disclosure. This study did not support the results of the previous studies showing that the mechanisms of corporate governance on the structure of the board can influence CSR investments. The results of the study indicated that the mechanism of efficient corporate governance can produce a strong level of CSR performance. The results of this study also did not support agency theory stating that the closer the relationship between the company and stakeholders is, the more active the investment in CSR will be. Therefore, the company could be more maximizing its social activities and disclosed them in financial statements.

Hypothesis 3 stated that corporate governance has a positive effect on the quality of the company's financial statements. Based on table 4, the significance value was 0,000 , below 0.05 . However, the beta was positive; so that, corporate governance would have a positive effect on earnings management (proxy for quality of financial statements). The conclusion that could be drawn was that hypothesis 3 was rejected because good governance would further reduce the quality of the company's financial statements. This showed that this result was not in accordance with the agency theory stating that good supervision will not be able to control the behavior of the directors for directors want greater personal benefits than the interests of the company.

\section{CONCLUSION, IMPLICATION, SUGGES- TION, AND LIMITATIONS}

Based on the results of multiple linear regression test and Sobel test, it can be drawn two conclusions. First, the disclosure of CSR conducted by the company proves to be significantly and negatively affecting earnings management. Company disclosing CSR will reduce its earnings management level to improve the financial statements quality. With the increasing quality of the financial statements, the disclosure of CSR has a positive effect on the quality of the company's financial statements. The second conclusion is that the direct influence of corporate governance on the financial statements quality as measured by earnings management significantly and negative- 
ly related. However, there is no CSR disclosure mediation on the effect of corporate governance on the quality of the financial statements. This shows that CSR disclosure of the quality of financial statements is in accordance with the agency theory, in which managers try to express the company's CSR activities in order to obtain personal benefits for their interests.bagi mereka.

This study has limitations related to samples which used only within the scope of manufacturing firms, so the scope is not broad enough. Besides, other limitations are related to the coefficient value of the determination (R2), which is still very low; 0.191 for model 1 and 0.123 for model 2; so that, the independent variable can only explain a little over the dependent variable.

Based on the existing limitations, it is suggested further research needs to extend the scope of the sample; so that, it becomes more widespread throughout the company. In addition, it is necessary to add other factors that may affect the financial statements quality. Companies need to pay attention to other factors that may affect the financial statements quality even though this research proves that CSR disclosure and corporate governance can affect the financial statements quality as measured by earnings management significantly.

\section{REFERENCES}

Anderson, R. C., Mansi, S. A., \& Reeb, D. M. (2004). Board Characteristics, Accounting Report Integrity, and the Cost of Debt. Journal of Accounting and Economics, 37(3), 315342.

Boyd, B. K. (1995). CEO Duality and Firm Performance: A Contingency Model. Strategic Management Journal, 16(4), 301-312.

Chariri, A., \& Ghozali, I. (2001). Teori Akuntansi (1st ed.). Semarang.

Chiang, H., He, L. J., \& Shiao, C. F. (2015). Financial Reports Quality and Corporate Social Responsibility. Asian Economic and Financial Review, 5(3), 453-467.

Chih, H.-L., Shen, C.-H., \& Kang, F.-C. (2008). Corporate Social Responsibility, Investor Protection, and Earnings Management: Some International Evidence. Journal of Business Ethics, 79(1-2), 179-198.

Cohen, D. A., Dey, A., \& Lys, T. Z. (2008). Real and Accrual-based Earnings Management in the Pre- and Post- Sarbanes Oxley Periods. The Accounting Review, 83(3), 757-787.

Core, J.E., R.W. Holthausen and D.F. Larcker,
1999. Corporate governance, chief executive officer compensation, and firm performance. Journal of Financial Economics, 51(3): 371406.

Dechow, P.M., R.G. Sloan and A.P. Sweeney, 1996. Causes and consequences of earnings manipulation: An analysis of firms subject to enforcement actions by the SEC. Contemporary Accounting Research: 136.

Dhaliwal, D., Li, O. Z., Tsang, A., \& Yang, Y. G. (2014). Corporate social responsibility disclosure and the cost of equity capital: The roles of stakeholder orientation and financial transparency. Journal of Accounting and Public Policy, 33(4), 328-355.

Endri. (2007). Konsep Corporate Social Responsibility dan Praktiknya di Indonesia. Ilmu Dan Budaya, 28(8).

Ghozali, I. (2011). Aplikasi Analisis Multivariate dengan Program IBM SPSS 19.Semarang: Badan Penerbit Universitas Diponegoro.

Halim, J., Meiden, C., \& Tobing, R. (2005). Pengaruh Manajemen Laba pda Tingkat Pengungkapan Laporan Keuangan pada Perusahaan Manufaktur yang Termasuk dalam Indeks LQ-45. SNA VIII Solo, 117-135.

Hillman, A. and T. Dalziel, 2003. Boards of directors and firm performance: Integrating agency and resource dependence perspectives. Academy of Management Review, 28(3): 383396.

Jensen, M. C., \& Meckling, W. H. (1976). Theory of the Firm: Managerial Behavior, Agency Costs and Ownership Structure. Journal of Financial Economics, 3, 305-360.

Karnani, A. (2010). The Case Against Corporate Social Responsibility. Wall Street Journal, 23, $1-5$.

Kim, I., \& Venkatachalam, M. (2011). Are Sin Stocks Paying the Price for Accounting Sins? Journal of Accounting, Auditing \& Finance, 26(2), 415-442.

Kothari, S. P., Leone, A. J., \& Wasley, C. E. (2005). Performance Matched Discretionary Accrual Measures. Journal of Accounting and Economics, 39(1), 163-197.

Lee, P. M., Neill, H. M. O., \& Lee, P. M. (2009). Ownership Structures and R \& D Investments of U . S . and Japanese Firms: Agency and Stewardship Perspectives. Academy of Management Journal, 46(2), 212-225.

Prior, D., Surroca, J., \& Tribó, J. A. (2008). Are Socially Responsible Managers Really Ethical? 
Exploring the Relationship between Earnings Management and Corporate Social Responsibility. Corporate Governance, 16(3), 160177.

Reinhardt, F. L., Stavins, R. N., \& Vietor, R. H. K. (2008). Corporate Social Responsibility through an Economic Lens. Faculty Research Working Papers Series.

Roychowdhury, S. (2006). Earnings Management through Real Activities Manipulation. Journal of Accounting and Economics, 42(3), 335370.

Salawski, M \& Zulch, H. (2012). The Impact of Corporate Social Responsibility on Financial Reporting Quality Evidence from European Blue Chips. HHL Working paper

Shahwan, T. M. (2015). The Effects of Corporate Governance on Financial Performance and Financial Distress: Evidence from Egypt. Corporate Governance, 15, 641-662.

Shivdasani, A. and D. Yermack, 1999. CEO involvement in the selection of new board members: An empirical analysis. Journal of Finance, 54: 1829-1853.

Susanti (2017). Pengaruh Leverage, Likuiditas, Ukuran Perusahaan, dan Kualitas Audit Terhadap Kualitas Informasi Laporan Keuangan. Akuntansi Dewantara, 1(1), 85-95.

Tanudjaja, B. B. (2006). Perkembangan Corporate Social Responsibility di Indonesia. Nirmana, 8(2), 92-98.

Yintayani, N. I. N. (2011). Faktor - faktor yang memengaruhi Corporate Social Responsibility (Studi Empiris pada Perusahaan yang Terdaftar di Bursa Efek Indonesia Tahun 2009).

$\mathrm{Yu}$, W. (2008). Accounting-Based Earnings Management and Real Activities Manipulation.

Yusnita, H., Mulyadi, \& Erick. (2015). Pengaruh Manajemen Laba Akrual dan Aktivitas Manajemen Laba Riil Terhadap Kinerja Perusahaan. JAFFA, 03 No. 01, 1-16. 